\title{
Hydrogeological Features of Mount Fuji and the Surrounding Area, Central Japan: An Overview
}

\author{
Danda Pani Adhikari \\ Department of Geology, Tri-Chandra Campus \\ Tribhuvan University, Nepal \\ E-mail: adhikaridp@ntc.net.np
}

\begin{abstract}
Mount Fuji (3776 m), Japan's highest mountain and one of the world's most picturesque stratovolcano was studied to give an overview of its hydrogeological features. The mountain was made from voluminous lava flows and pyroclastic materials produced through three generations of volcanic activities. The volcanic products, characterized by abundant pore spaces and fractures, play a role as productive aquifers by absorbing and storing rain and snow melt as groundwater and releasing it over a long period. Its foot slopes contain abundant water with Fuji-Five-Lakes in the north and hundreds of springs with enormous discharge to the south, leaving the upper slopes dry. Approximately 2.2 billion tons of rain and snow fall annually at Mt. Fuji, and $\sim 4.5$ million tons of groundwater is stored each day in average. The total amount of spring or groundwater discharge from Mt. Fuji is estimated at $6.55 \times 106 \mathrm{~m}^{3} /$ day and that in its southwestern slopes is $\sim 1.76 \times 106 \mathrm{~m}^{3} /$ day. Rain and snow falling above the altitude of $\sim 1,000 \mathrm{~m}$ is their main source of recharge. The water provides vital resources for the people living around it; however, over exploitation of this resource have already caused some decline in its quality and quantity.
\end{abstract}

Key words: Mount Fuji, stratovolcano, lava flow, pyroclastic materials, aquifer, hydrogeology, spring, groundwater.

\section{INTRODUCTION}

Mount Fuji (Fuji-San) is the highest volcanic mountain (3,776 $\mathrm{m}$ above sea level) in Japan. It is located about $110 \mathrm{~km}$ west of Tokyo close to the Pacific coast at the border between Yamanashi and Sizuoka Prefectures $\left(35^{\circ} 21^{\prime} \mathrm{N}, 138^{\circ} 43^{\prime} \mathrm{E}\right)$ in southern Honshu Island (Fig. $1)$. The mountain rises above the Pacific coast in the south and the summit part stands about 2,900 m above the surrounding plain in the north. It has a diameter of about $50 \mathrm{~km}$ and circumference of $153 \mathrm{~km}$ at the base, and it displays gracefully curving slopes (Figs. 2 \& 3) diminishing from $32^{\circ}$ near the summit to $25-27^{0}$ in the middle to almost level at the base (Tsuya, 1971). Its body surface area is about $960 \mathrm{~km}^{2}$ and volume about 1,400 $\mathrm{km}^{3}$. The summit of the mountain has a circular crater of $\sim 500 \mathrm{~m}$ across and $\sim 250 \mathrm{~m}$ deep below the highest point (Fig. 3). The upper slope of the mountain is virtually dry, whereas lower slopes contain abundant water of good quality.

Mt. Fuji's height and volume, eminent snow-capped peak, and symmetrical beauty of flank lines (Figs. 2 \& 3 ) has become a symbol of Japan, and is designated as the UNESCO World Heritage Site. Besides its scenic beauty and geological importance, the mountain is a cultural icon to the people of Japan and its images are held in high regard. The foot of the Volcano is densely populated with about a half million people living around. The mountain's magnificent view and wilderness of the area attracts more than 30 million domestic and foreign visitors every year and about 0.40 million of them climb it during June-August (Personal communication to local people).

Mt. Fuji is a large composite volcano (stratovolcano), which consists of alternating pyroclastic materials and lava flows (Fig. 4). Pyroclastic materials include fragmented particles of different diameters, such as dust $(<0.25 \mathrm{~mm})$, ash $(0.25-2 \mathrm{~mm})$, lapilli or small stone (2$64 \mathrm{~mm})$, cinders, and block/bomb (>64 mm). Magma contains gases and when it comes on the surface they expand several times in response to the reduced pressure producing highly porous vesicular rocks. Owing to their nature and structure, volcanic materials can be good reservoirs that absorb and store rain and snow melt water as groundwater and release it over a long period. Hydrologic knowledge involving mode of occurrence of water, storage capacity, and water balance in a volcanic terrain makes it possible to evaluate the water potential of such reservoirs. 


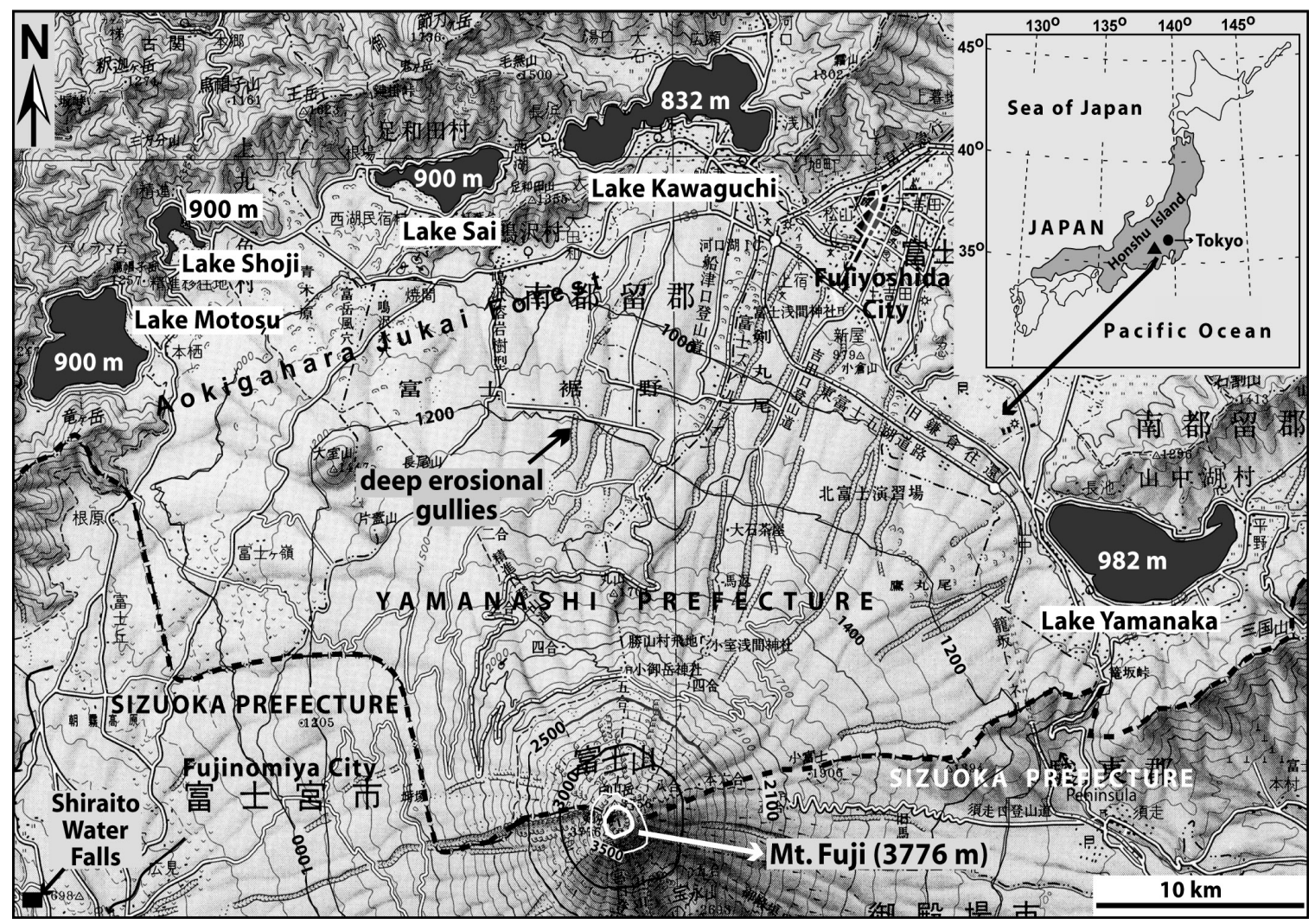

Fig. 1. Location and topographical map of Mt. Fuji and the surrounding area, central Japan. Fuji-Five Lakes, Aokigahara Jukai Forest, Shiraito Water Falls, and the boundary between the Yamanashi and Sizuoka Prefectures are shown. Topographic contours are at $100 \mathrm{~m}$ intervals (adopted from the topographic map, Geographical Survey Institute of Japan, Fuji-San, 1:25,000).

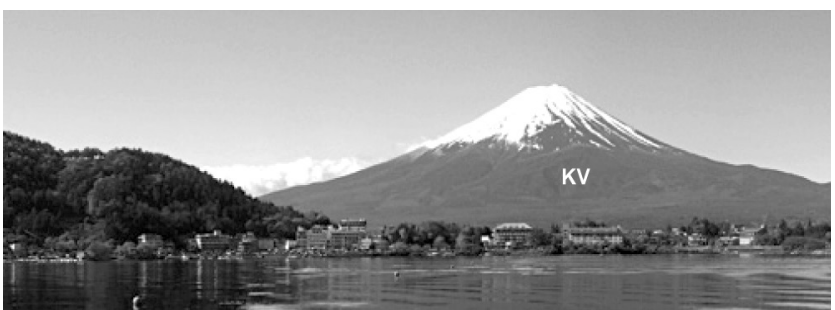

Fig. 2. Photograph of Mt. Fuji with Lake Kawaguchi on background (approximately $15 \mathrm{~km}$ to the north). KV: Komitake Volcano (seen separate from the main body in the frontal part). Geographical position of Lake Kawaguchi in relation to other Fuji-Five Lakes is shown in Fig. 1.

However, volcanic rocks have complex hydraulic features due to their great textural and lithological variability, different level of weathering, and their complex spatiotemporal distribution (Vernier, 1993), which could compartmentalize the regional hydogeologic system into several domains (Gmati et al. 2011). The objective of this article was to give a comprehensive overview of the aquifer settings and movement and mode of occurrence

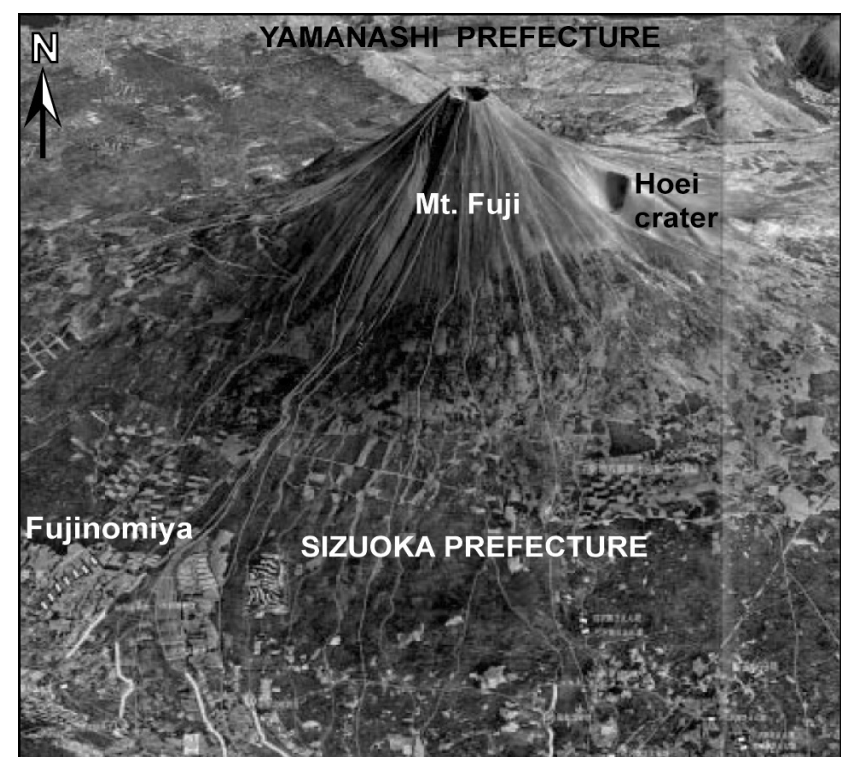

Fig. 3. Arial view of Mt. Fuji $(3,776 \mathrm{~m}) \&$ the surrounding area. The Hoei crater created by the last eruption of Mt. Fuji (AD 1707-08) is visible on the southeast side below the summit crater. 
of water around Mt. Fuji. Specifically, the article aims at providing better understanding of intricate relationships of recharge, storage, groundwater flow, and discharge in a volcanic terrain that manifests its hydrogeological work as several lakes, springs, and provides quality water for anthropogenic use.

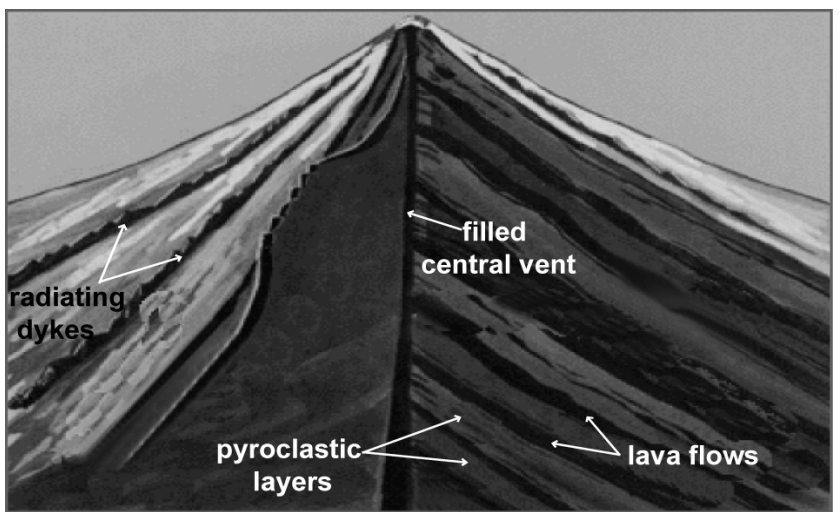

Fig. 4. Schematic diagram illustrating the internal structure of Mt. Fuji.

\section{MATERIALS AND METHODS}

The hydrogeological condition of a given area is the results of interaction of two active agents- the solid and the fluid. The solid aspect comprises the material and the geometry of an aquifer and the hydraulic properties of the aquifer; the fluid aspect involves the hydraulic behavior of the groundwater. The solid and liquid aspects of Fuji Volcano as a whole formed the material of this study. Field excursions were undertaken in the northern foot of Mt. Fuji in several occasions to understand the geology and hydrology of the Fuji-Five Lakes area in connection with paleolimnological investigation of Lake Yamanaka (Fig. 1). The mountain was climbed up to the top for more information on the upper mountain slopes, and hydrogeological observations were made around Fujinomiya, southwestern part of Mt. Fuji (Fig. 1) where springs are abundant. In addition, relevant information on Mt. Fuji, volcanic materials, and hydrogeology of the area were collected from existing literatures.

\section{RESULTS AND DISCUSSIONS General Features Climate}

Mt. Fuji area has three climatic zones - humid temperate below $1,600 \mathrm{~m}$, subalpine in middle part, and alpine above $2,500 \mathrm{~m}$ altitude. The temperature decreases by $0.60{ }^{\circ} \mathrm{C}$ with each $100 \mathrm{~m}$ increase in elevation (Japan Meteorological Agency, 2011). Excluding parts of summer, the monthly average temperature at the peak is almost always below freezing and the annual average is $-7.10{ }^{\circ} \mathrm{C}$. At the summit, the highest and lowest recorded temperatures were $17.80^{\circ} \mathrm{C}$ and $-38.00^{\circ} \mathrm{C}$ in August 1942 and February 1981, respectively (Japan Meteorological Agency, 2011).

Annual precipitation in the area varies from 2,750 to $3,000 \mathrm{~mm}$ on the wettest, east slope (sea facing slopes) and from 1,500 to 2,000 $\mathrm{mm}$ on the north slopes (Kizawa et al. 1969). Most of the moisture supply to the area is derived from Sagami Bay and Suruga Bay in the south through south-easterlies or southerlies or from both winds. Much of the precipitation in the summit and upper mountain slopes from October through April falls as snow, and the average snow accumulation during 19582004 was $188 \mathrm{~cm}$ (Tsuchi, 2007). The upper half of the mountain is completely covered by snow in winter (Fig. 2 ), and small patches of permanent icy snow left on the shady slopes in and around the summit crater are usually seen even in midsummer (Adhikari, 2012). But, traces of past glaciations are found nowhere on the mountain (Tsuya, 1971). The evaporation rate ranges from 12 to $28 \%$ of the annual precipitation for the north slopes and from 11 to $24 \%$ for the south. At a given elevation, the evaporation rate from the north flank is 2 to $7 \%$ higher than that from the south flank, and is attributed to a longer duration of sunshine and lower humidity in summer time on the north flank than on the south flank (Yashuhara et. al., 2007).

Mt. Fuji has an alpine timberline ecotone with vegetation up to the altitude of about 2,400-2,500 m above sea level. The timberline vegetation comprised three dwarf tree species, viz., Alnus maximowiczii, Salix reinii and Larix kaempferi (Sakio \& Masuzawa, 2012). The common trees in the lower slopes are species of pine, rhododendron etc. The apical part above $3,000 \mathrm{~m}$ is virtually barren, forming steep slopes and bluffs covered either with lava flows or with ash fall deposits (Fig. 3).

\section{Geology}

Mt. Fuji's present shape was created over three generations of volcanic activities, namely, the Ko-Mitake (literally meaning 'small mountain volcano'), Ko-Fuji (Older Fuji), and Shin-Fuji (Younger Fuji) volcanoes (Miyaji et al. 1992). A generalized geologic map with distribution of major categories of rock types around Fuji Volcano is shown in Fig. 5. The Ko-Mitake volcano, which was active between 700 and 200 thousands of years before present (ka) (middle Pleistocene Epoch), produced andesitic lava, agglomerate, and pyroclastic materials (Tsuya, 1971). The Ko-Mitake can be seen in 
the northern slope of Mt. Fuji at the Fifth Station (the terminal parking lot of the highway called 'Subaru Line', Figs. 2 \& 6). The volcano then underwent dormant (inactive) for some times and followed by another phase of volcanic activities during $100 \mathrm{ka}-11 \mathrm{ka}$ which is known by the Older Fuji Volcano (OFV) (Miyaji et al. 1992). The OFV released voluminous pyroclastic falls (scoria and ash), lava flow, and large scale mudflows ('Older Fuji mudflows' generated from pyroclastic-flows and debris-avalanche deposits). The volcano formed a separate, $\sim 3,100 \mathrm{~m}$ high mountain in the southern side of Mt. Ko-Mitake as illustrated in Fig. 6. Total volume of ejecta from the OFV is estimated at $250 \mathrm{~km}^{3}$ and it formed the base of the current Mt. Fuji (Miyaji et al. 1992).

The Younger Fuji Volcano (YFV) started erupting basaltic lava for the first time in its history $\sim 11 \mathrm{ka}$ and exploded repeatedly for over 100 times (Miyaji, 2002) since then creating the mountain's current shape and dimensions (Figs. 2, $3 \&$ \& ). Its activities are characterized by eruptions of different types and natures, such as summit crater eruptions, summit and flank-fissure eruptions, major lava flows and minor pyroclastic falls etc. The last eruptions of December 1707-January 1708, known by Hoei eruption (Hoei dai funka), is the largest of all eruptions in recorded history of Fuji Volcano, and by nature it was the largest scoriaceous Plinian eruption (culminate in violent explosive eruptions) with a parasitic crater in the southeastern part of the mountain (Fig. 3). It released $\sim 1.7 \mathrm{~km}^{3}$ pyroclastic materials (Miyaji, 1988); three meters of debris accumulated at the foot of Mt. Fuji and $>6 \mathrm{~cm}$ of ash blanketed Tokyo area. Lava flow did not occur during the YFV period, whereas the total volume of all erupted products is estimated to be $47 \mathrm{~km}^{3}$ (Miyaji, 2002).

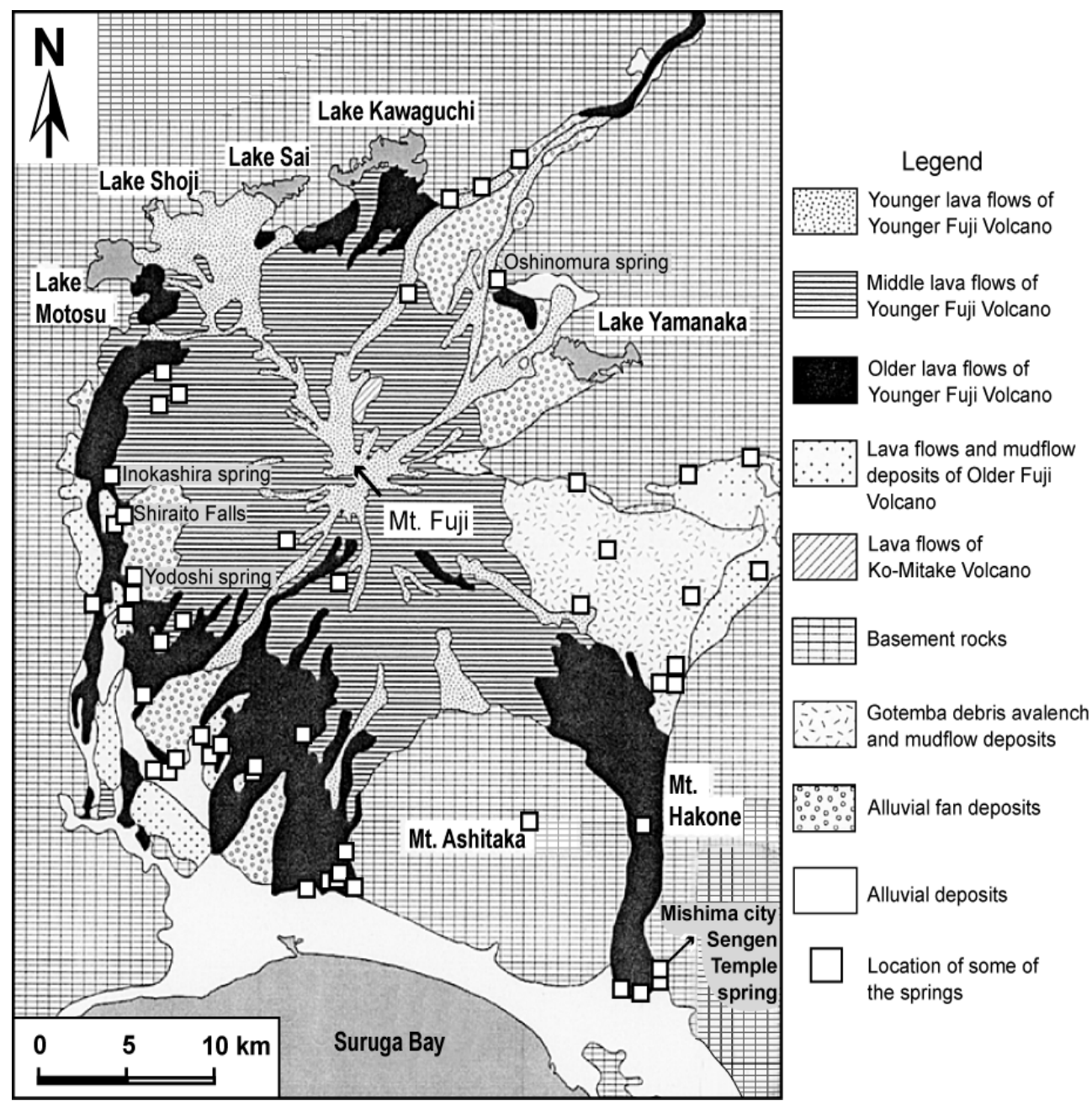

Fig. 5. General geological map of Mt. Fuji area with location of Fuji-Five-Lakes and some of the springs and waterfalls (modified from Machida, 1977; Yamamoto, 1970; Tsuya, 1968). 


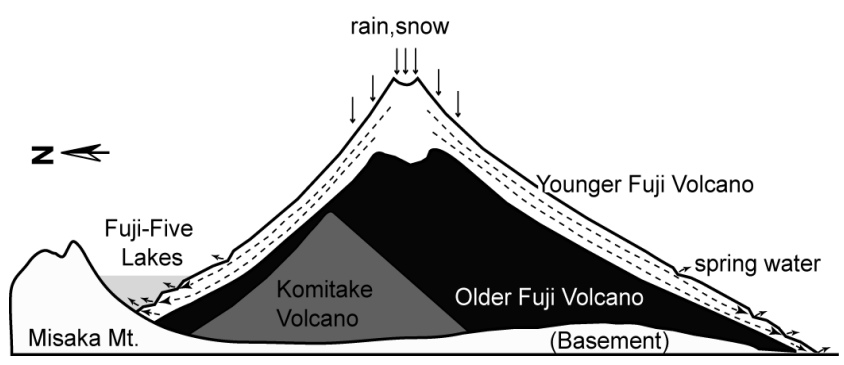

Fig. 6. Schematic cross section showing hydrogeologic structures and groundwater flow in Mt. Fuji (modified from Tsuchi, 2007).

\section{Aquifer setting and water movement}

Bodies of rocks or soils, or both, which contain significant quantities of water that can be tapped by wells or springs are aquifers. Both consolidated and unconsolidated geological materials are important as aquifers. From the perspective of hydrogeology the important characteristics of rocks are how much open space is available in between the crystals or fragments to hold water (porosity) and how well the open spaces are connected to allow water to flow (permeability). The spaces between mineral grains of a rock are referred to as inter-granular porosity. Many volcanic rocks are fractured because of their relatively rapid cooling or violent formation and give rise to fracture porosity too.

Most of the volcanic materials on the surface around Mt. Fuji are composed of the YFV as materials from OFV are covered by the thick deposits of the YFV. In most localities the scoria-fall deposit is composed of massive bed of reddish-brown lapilli. The tephra clasts are dominantly angular to sub-angular and display a wide range in vesicularity from frothy scoria to dense, fresh fragments with few vesicles. The color of the tephra varies between light reddish and dark-gray. The prevalence of scoria fall deposits on the surface and fracturing in the rocks around Mt. Fuji area, as shown in Fig. s 7a, b, \& $\mathrm{c}$, have given rise to inter-granular and fracture porosity high, making them as excellent aquifers.

The geological units that serve as aquifers in Fig. 5 include: 1) alluvial deposits in the lowland and volcanic ash beds (pyroclastic materials) on the surface of the mountain as superficial aquifer; 2) the lava flows of YFV (older, middle, and younger lava flows) as main aquifer (new Fuji aquifer); and 3) the pyroclastic mudflow deposits of the OFV as minor aquifer (old Fuji aquifer). Tsuchi (2007) gave an explanation of the reason behind
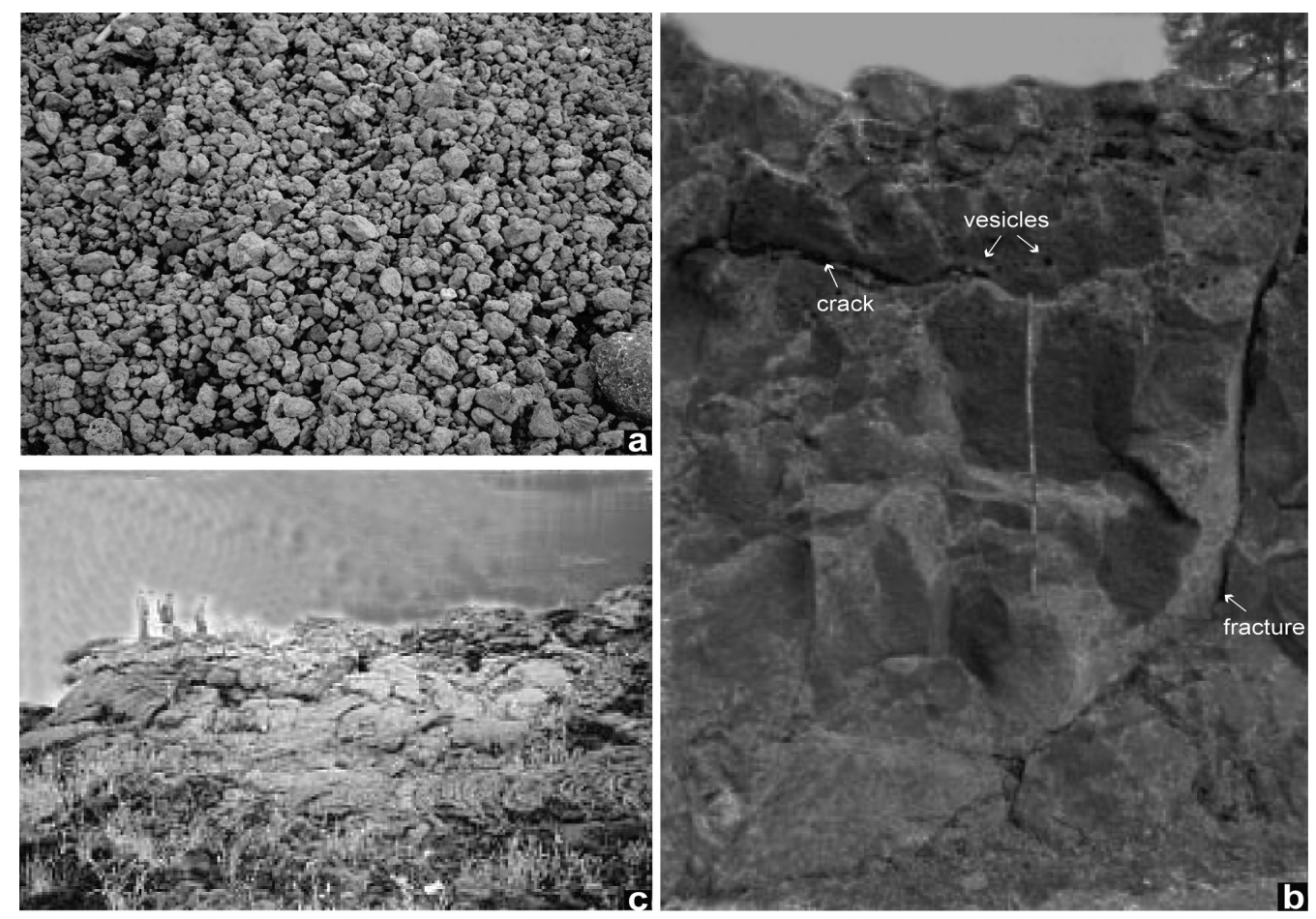

Fig. 7 (a). Close up view of the scoria fallout deposits as it seen in the upper mountain slopes and summit part of Mt. Fuji; (b). Outcrop of Aokigahara Lava Flow of Younger Fuji Volcano with vesicles and high fracture porosity at Narusawa-Michinoeki (after Takahashi et al. 2007); (c). Thin part of the Aokigahara Lava Flow at the edge of Lake Sai. The rock is mostly left uncovered with volcanic ash and other pyroclastics and groundwater in the lava discharges directly into lake and form the predominant source of recharge (after Yasuhara et al. 2007). 
YFV lava becoming the main aquifer - basaltic lava during eruption attains ca. $1,200{ }^{\circ} \mathrm{C}$ and the surface and bottom parts of the lava flow are cooled rapidly and crushed, becoming clinker as illustrated in Fig. 8, whereas the lava in the inner part cools slowly and solidifies densely. The lava in the steeper parts of the cone in high altitude, on the other hand, becomes thin and crushed. The crushed and permeable parts (clinkers) existing between the lava layers (Fig. 8) present the "route" through which the groundwater flow and they may constitute "the water-bearing horizons". The precipitation stored as groundwater in the crushed parts between the lava layers in the foot area is pushed out on the surface because of the water pressure from higher elevation.

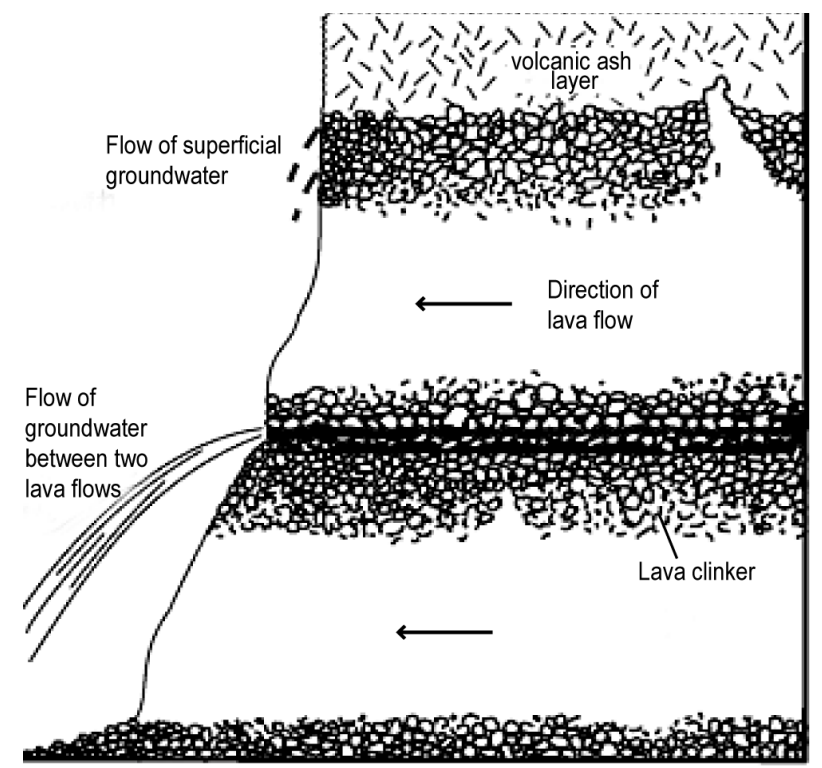

Fig. 8. Schematic diagram showing the unpressured underground waters in surface volcanic ash beds and pressured groundwater within overlapping basaltic lava flow beds (after Tsuchi, 2007).

Basaltic rocks constitute many overlapping lava flows with various length and width, and they are well known for their abundant joints and fractures and high permeability resulting from that (Demlie et al. 2007; Koh et al. 2005). Based on the identical features seen around Mt. Fuji, Gmati et al. (2011) hypothesized vertical interconnection between the water-bearing horizons of the New Fuji Lava as the mechanism of aquifers interaction (Fig. 9). The diagram shows that besides the horizontal clinkers responsible for the horizontal groundwater flow, lateral clinkers separating the lava blocks of different and limited lateral extents could play an important role in the percolation of groundwater downward causing groundwater mixing (Gmati et al. 2011). Gmati et al. (2011), using groundwater geochemical signatures and hierarchical cluster analysis, highlighted three interacting groundwater systems in the southwestern foot of Mt. Fuji: (1) Shallow flow system locally and recently recharged and prevailing the superficial aquifer; (2) Deep flow system of the Old Fuji Aquifer (groundwaters draining this aquifer are of great residence time and recharged at higher altitudes); and (3) the flow system draining the New Fuji Lava layers acting as a connector between the above mentioned systems. Previously, Yamamoto (1970) proposed divisions on hydrologic structure of Mt. Fuji, classifying volcano body into three zones as upper recharging zone, middle recharging zone, and spring zone (Fig.10).

\section{Water distribution}

The flanks and lower mountain slopes of Mt. Fuji are sculptured by a number of radial valleys and erosional gullies, none of which however has usual surface stream except during occasional torrential rain events in summer and typhoon seasons and sudden snow melt in spring (Tsuya, 1988). The lack of surface streams is due to the fact that the pyroclastics and the lava flows of the YFV are highly permeable and water on the surface easily percolates through the porous media. Below the YFV, the mudflows and pyroclastic deposits of the OFV are impermeable and the water percolating down from the surface layer could not move further deep and stored as groundwater, and appears, at the foot of Mt. Fuji as springs or waterfalls where the boundary between the OFV and YFV is exposed (Koshimizu \& Tomura, 2000). Given the difference in topography and aquifer distributions in the north and the south, water movement and distribution in these two slopes differ in some ways as summarized below.

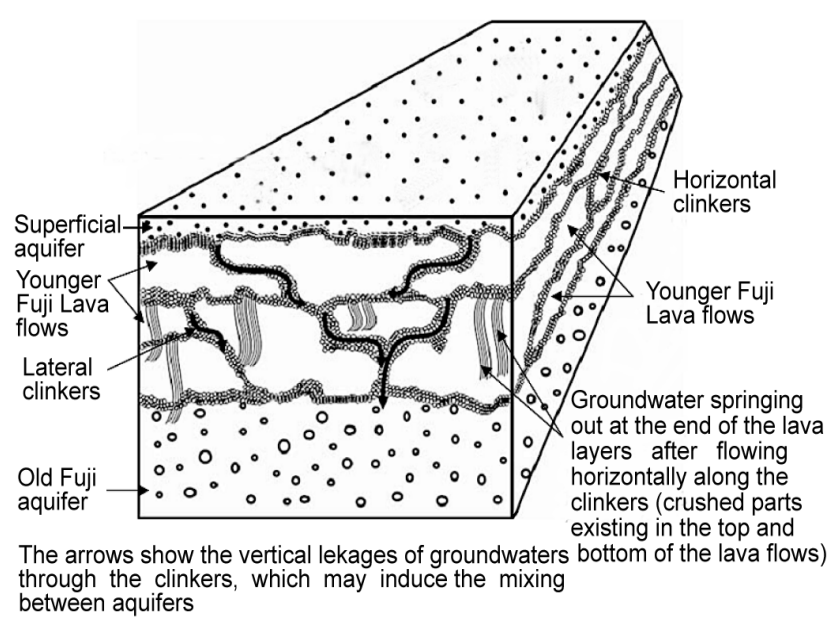

Fig. 9. Conceptual diagram illustrating the aquifers interactions around Fuji Volcano area (modified after Gmati et al. 2011). 


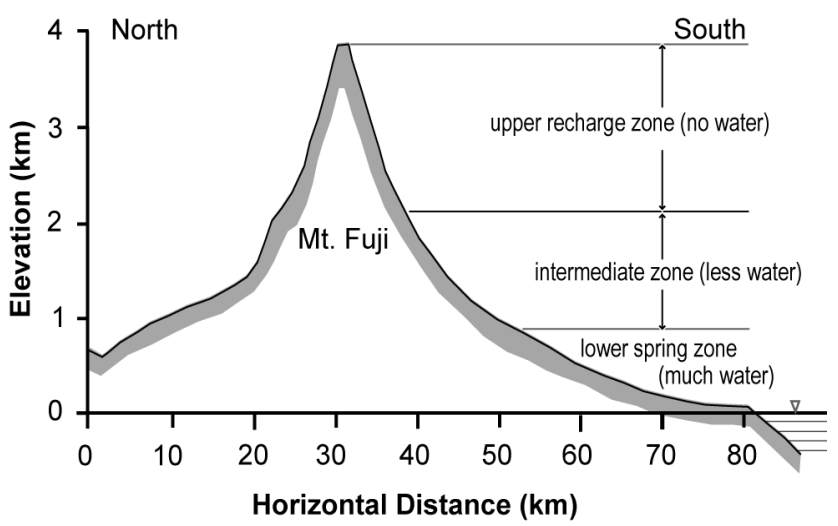

Fig. 10. Mt. Fuji flank slopes divided into three zones on the basis of water availability (modified after Yamamoto, 1970).

\section{Northern Slope}

Northern foot of Mt. Fuji is popularly known as FujiFive Lakes (Fuji Goko in Japanese) as it hosts five lakes, namely, Lake Yamanaka, Lake Kawaguchi, Lake Sai, Lake Shōji, and Lake Motosu from east to west (Fig. 1). The lakes were formed by damming of preexisting streams by lava flows from Mt. Fuji (Adhikari, 2011; Koshimizu \& Uchiyama, 2002). In the catchments of the Fuji-Five Lakes, the boundary between the OFV and YFV is rarely exposed on the surface and due to this hydrogeological character most of the percolating water and snow melts directly contribute to the lake internally, at some depths below the lake surface, rather than appearing as overland flow or streams (Koshimizu \& Tomura, 2000) (Fig. 6). Table 1 summarizes some of the physical characteristics of the Fuji-Five Lakes.

Among the Five-Lakes, Lake Yamanaka is closest (12 $\mathrm{km}$ ) to Mt. Fuji and located at the highest elevation (982 m) (Fig. 1). The lake is the largest in terms of surface area and the shallowest with a maximum water depth of 14.00 $\mathrm{m}$ (Table 1). Lake Yamanaka is drained by the Sagami River, and it is the only of the Fuji-Five Lakes to have a natural outflow. Lake Kawaguchi, on the other hand, is at the lowest elevation $(832 \mathrm{~m})$, second largest (surface area, $6.13 \mathrm{~km}^{2}$ ), and has the longest shoreline (Fig. 1). The lake has no natural outlet. Lake Sai is the fourth largest in surface area and second deepest (maximum water depth: $71.10 \mathrm{~m}$ ). Surface elevation and shore length of Lake Sai are $900 \mathrm{~m}$ and $9.85 \mathrm{~km}$, respectively (Table 1). Lake Sai has no natural drainage, but an artificial channel now connects it to Lake Kawaguchi. Located at $900 \mathrm{~m}$ elevation, Lake Shōji is the smallest in area $\left(0.50 \mathrm{~km}^{2}\right)$ but the third deepest (maximum water depth: $15.20 \mathrm{~m}$ ) lake. Lake Motosu is the deepest among the Five-Lakes $(140 \mathrm{~m})$ and the ninth deepest lake of Japan (Koshimizu \& Tomura, 2000). Like Lake Sai and Lake Shōji, Lake Motosu is $900 \mathrm{~m}$ high in elevation and it holds the largest volume of water. Lake Sai, Lake Yamanaka, Lake Kawaguchi, and Lake Shōji are in descending order in terms of water volume in the lakes (Table 1).

The western three lakes, Lake Motosu, Lake Sai and Lake Shōji experience similar seasonal rise and fall in water levels. Their similar surface elevation and similar fluctuations indicate that these three lakes remain connected by underground waterways. Research findings (e. g. Rafferty, 2010; Takahashi et. al. 2007) suggest that these three lakes were originally a single, big lake which was later divided by enormous $\left(\sim 1.40 \mathrm{~km}^{3}\right)$ lava flows of Aokigahara Lava from Mt. Fuji during AD 864-868. Seen as thousands of flow lobes, the Aokigahara Lava (characterized by high fracture porosity, Fig. $7 b$ \& c) widely covers the northwestern foot of the volcano and the remnants of which are seen in the Aokigahara Jukai Forest (Fig. 1). The Aokigahara Lava is the largest lava flow of the YFV (Takahashi et al. 2007). Besides the FujiFive Lakes, few springs emerge in some places in the mountain between Lake Yamanaka and Lake Kawaguchi where the boundary between the OFV and YFV exposes (Fig. 5), and the Oshinomura Spring with discharge of 2,223 liters/second (L/s) (Yamamoto, 2070) is the largest spring in the northern foot of Mt. Fuji.

The relative rate of direct flow of groundwater to the FujiFive Lakes is not well known, but the lack of perennial surface inlets and relatively high lake discharges suggest that water budget is entirely the contribution of groundwater flow (Koshimizu \& Tomura, 2000). There has been no large changes in lake level in response to extended periods of drought or high rainfall, but few centimeters of water level rise occurs each year during rainy and snowmelt seasons (personal communication to local people in Fuji-Five Lakes area).

\section{Southern slope}

Unlike the northern part, the southern part of Mt. Fuji hosts few lakes but large number of springs as the boundary between the OFV and YFV is exposed on the surface. Locations of some of the springs are shown in Fig. 5, and some of them are big and geometrically high enough to develop themselves as waterfalls. Shiraito Falls (Shiraito means Silk thread in Japanese) in Fujinomiya (Fig. 11a), for example, constitutes of over 200 small waterfalls and each of them looks like a silk line, and in group they make beautiful white water curtain. It is 20 
$\mathrm{m}$ high and $200 \mathrm{~m}$ wide, and is the largest of all in the area. Additional unique feature of Shiraito Falls is it does not have river run into the fall. The water volume from Shiraito Falls is estimated at $\sim 1,382 \mathrm{~L} / \mathrm{s}$ (Yamamoto, 1970), and it discharges to Shiba River. Sometimes Shiraito Falls is called as Japanese Niagara Fall. It has been protected as a Japanese Natural Monument and in 2013 the waterfall was added to the World Heritage List as part of the Fujisan Cultural Site.

Otodome Falls is right next to the Shiraito Falls, and is $\sim 25 \mathrm{~m}$ high and $5 \mathrm{~m}$ wide (Fig. 11b). These two falls are listed as two of the 100 best waterfalls in Japan. Jimba Falls is located just north of Lake Tanuki, which has a surface area of $0.312 \mathrm{~km}^{2}$ with $1 \mathrm{~km}$ length, $0.5 \mathrm{~km}$ width, and $8 \mathrm{~m}$ average depth. Wakutama and Kohama are spring ponds in Mishima. There are 13 springs, among hundreds, with variable discharge from $80 \mathrm{~L} / \mathrm{sec}$ to over $1000 \mathrm{~L} / \mathrm{sec}$ (Yamamoto, 1970).

Based on the oxygen and hydrogen isotope analysis of spring waters, rainwater and snow falling above the

Table 1: Physical characteristics of Fuji-Five Lakes

\begin{tabular}{|l|c|c|c|c|c|}
\hline Name of Lake & Lake Yamanaka & Lake Kawaguchi & Lake Sai & Lake Shoji & Lake Motosu \\
\hline Surface elevation (masl) & 981 & 832 & 900 & 900 & 900 \\
\hline Maximum depth $(\mathrm{m})$ & 13.50 & 15.20 & 71.10 & 15.20 & $140(67.3)$ \\
\hline Surface area $\left(\mathrm{km}^{2}\right)$ & 6.46 & 6.13 & 2.10 & 0.50 & 4.70 \\
\hline Shore length $(\mathrm{km})$ & 13.87 & 19.00 & 9.85 & 6.80 & 11.82 \\
\hline Water volume $\left(\mathrm{x} 10^{6} \mathrm{~m}^{3}\right)$ & 65 & 53 & 130 & 7 & 400 \\
\hline $\begin{array}{l}\text { Distance from Mt. Fuji } \\
\text { summit }(\mathrm{km})\end{array}$ & 12 & 15 & 13 & 15 & 13 \\
\hline
\end{tabular}

(Sources: Adhikari, 2011; Koshimizu \& Tomura, 2002; Yamamoto, 1970)

altitude of ca. 1,000 $\mathrm{m}$ is their main source of recharge and its underground residence time is 15 years (Yasuhara et al. 2007). Approximately 2.2 billion tons of rain and snow fall annually at Mt. Fuji, and excluding evapotranspiration, $\sim 4.5$ million tons of groundwater is stored each day in average (Yasuhara et al. 2007). Kakita River, which flows through the town of Shimizu in the Shizuoka Prefecture, Japan, alone receives over one million tons of water a day coming from the springs at the southern foot of Mt. Fuji. The total amount of springs or groundwater discharge from Fuji Volcano is estimated at $6.55 \times 106 \mathrm{~m}^{3} /$ day or $24 \times 108 \mathrm{~m}^{3} /$ year, and that in the west side of Mt. Fuji is $\sim 1.76 \times 106 \mathrm{~m}^{3} /$ day (Yasuhara et al. 2007).

The area's abundant groundwater and streams facilitate the operation of paper and chemical industries and farming. Cultivation of rainbow trout and dairy farming are other activities. In the last few years, groundwater has been developed or is about to be developed in quantities ranging from $1,400,000 \mathrm{~m}^{3}$ per day on southern part to 24, $000 \mathrm{~m}^{3}$ per day on northern part (Gmati et al. 2011). An extensive development of groundwater for industrial use as well as for agricultural activities has caused abrupt decline of groundwater pressure, stopping or decreasing of spring discharge, and groundwater contamination by sea water invasion.

\section{CONCLUSIONS}

Geology of Mt. Fuji plays an important role in the hydrological processes, including the occurrence and movement of groundwater in the area. This volcanic terrain with multi-layered lava flows and pyroclastic fall deposits make the Mt. Fuji a productive aquifer system. The Fuji-Five-Lakes (Lake Yamanaka, Lake Kawaguchi, Lake Sai, Lake Shōji, and Lake Motosu) in the northern side and hundreds of springs with enormous discharge in the southern side of the Mt. Fuji are the manifestation of excellent hydrogeological conditions in the area.

The Mt. Fuji aquifer systems result from pore spaces as well as the fractures in the rocks. The pyroclastic deposits are porous, and development of clinkers at the basal parts of the overlapping lava flow layers through crushing during rapid cooling of the Younger Fuji Volcano gave rise to additional pore spaces conducive for horizontal and vertical water movement. The aquifer setting in Mt. Fuji makes it a big reservoir which absorbs and store rain water in its body as groundwater and releases it over a long enough periods. Rainwater and snow falling above the altitude of ca. 1,000 $\mathrm{m}$ is their main source of recharge. About 2.2 billion tons of rain and snow fall annually at Mt. Fuji, and excluding evapotranspiration, $\sim 4.5$ million tons of groundwater is stored each day in average. The total amount of springs or groundwater discharge from 

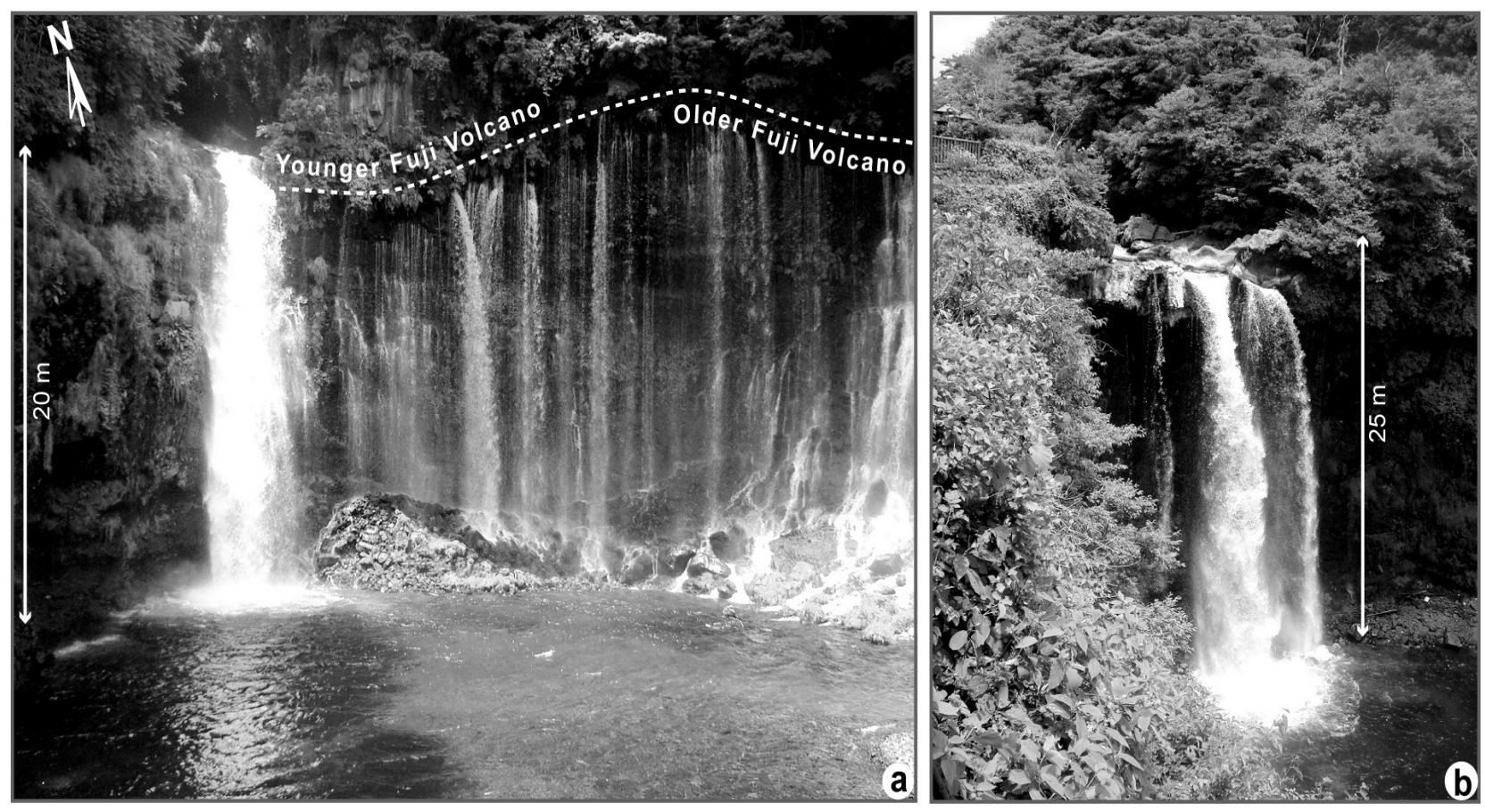

Fig. 11. Shiraito (a) and Otodome (b) Falls in Fujinomiya, southwestern part of Mt. Fuji. The springs are coming out of the contact between the Older and Younger Fuji Volcano.

Fuji Volcano is estimated at $6.55 \times 106 \mathrm{~m}^{3} /$ day or $24 \mathrm{x}$ $108 \mathrm{~m}^{3} /$ year, and that in the west side of Mt. Fuji is $\sim 1.76$ $\mathrm{x} 106 \mathrm{~m}^{3} /$ day.

Hydrogeologic knowledge involving mode of occurrence of water, storage capacity, and water balance make it possible to evaluate the water potentiality of this volcanic terrain as a groundwater reservoir. The extensive development of groundwater for industrial and agricultural uses around Mt. Fuji can change the existing hydrogeological balance in the area with unintended consequences such as decline in groundwater pressure, discharge, and quality. Therefore, it is important to understand the overall hydrogeological factors controlling the Mt. Fuji aquifer system for a sustainable use of this resource.

\section{ACKNOWLEDGEMENTS}

Field excursions and part of the literature review works were performed during Japan Society for the Promotion of Science (JSPS) fellowship during 2003-2005. The author is thankful to S. Koshimizu, Yamanashi Institute of Environmental Sciences, Japan for his supports in various ways. Comments from anonymous referees helped improve the manuscript.

\section{REFERENCES}

Adhikari, D.P. 2012. Geological features and history of Mount Fuji, Japan: An overview. Bulletin of Nepal Geological Society 29: 61-66.

Adhikari, D.P. 2011. Paleolimnology of Lake Yamanaka as reflected on particle size distribution. Bulletin of Department of Geology, TU 14: 35-42.

Demlie, M., Wohnlich, S., Wisotzky, R., Gizaw, B. 2007. Groundwater recharge, flow and hydrogeochemical evolution in a complex volcanic aquifer system, central Ethiopia. Hydrogeology Journal 15: 1169-1181. doi: 10.1007/s10040-007-0163-3.

Gmati, S., Norio, Tase, M., Tsujimura, M., Tosaki, Y. 2011. Aquifers interaction in the southwestern foot of Mt. Fuji, Japan, examined through hydrochemistry and statistical analyses. Hydrological Research Letters 5: 58-63.

Hanaoka, M., Tomita, Y., Ito, M. 2007. Osawa Kuzure (failure) and debris flows in Mt. Fuji. In: Fuji Volcano. (eds.) Aramaki, S., Fujii,T.Nakada, S. and Miyaji, N. Yamanashi Institute of Environmental Sciences, Yamanashi, Japan. 407-425p. 
Japan Meteorological Agency, 2011. http://www.jma. go.jp/jma/menu/report.html.

Kizawa, T., Iida, M., Matsuyama, S., Miyawaki, A. 1969. Mt. Fuji-Solving the Mystery of its Nature. NHK Books 91, NHK Tokyo, Japan, 253p.

Koh, D.C., Chang, H.W., Lee, K.S., Ko, K-S., Kim, Y., Park, W.B. 2005. Hydrogeochemistry and environmental isotopes of groundwater in Jeju volcanic island, Korea: Implications for nitrate contamination. Hydrological Processes 19: 2225-2245. doi:10.1002/hyp.5672.

Koshimizu, S. and Uchiyama, T. 2002. Geological outline of the borehole cores from Fuji-Five Lakes surrounding Mt. Fuji, central Japan. Daishiki 34: 9-18.

Koshimizu, S. and Tomura, K. 2000. Geochemical behavior of trace vanadium in the spring, groundwater, and lake water at the foot of Mt. Fuji, central Japan. In: Groundwater updates. (eds) Sato, K. \& Iwasa, Y. Springer-Verlag, Tokyo, Japan. 171-176.

Machida, H. 1977. Tephra: Its Characteristics and Relationship to the Japanese Quaternary Era. Soju-Shobo, Tokyo, Japan, 324p.**

Miyaji, N., Endo, K., Togashi, S., and Uesugi, Y. 1992. Tephrachronological history of Mt. Fuji. $29^{\text {th }}$ IUGG Field Trip, C12: 75-109.

Miyaji, N. 1988. History of Younger Fuji Volcano. Journal of Geological Society of Japan 94: 433452.

Miyaji, N. 2002. The 1707 eruption of Fuji volcano and its tephra. Global Environmental Research 6(2): 37-39.

Rafferty, J.P. 2010. Plate Tectonics, Volcanoes, and Earthquakes. Rosen Publishing, New York, USA, 288p.

Sakio, H. and Masuzawa, T. 2012. The advancing timberline on Mt. Fuji: natural recovery or climate change? Journal of Plant Research 125: 539-546.
Takahashi, M., Matsuda, F., Yasui, M., Chiba, T., Miyaji, N. 2007. Geology of the Aokigahara Lava Flow Field in Fuji Volcano and its Implications in the Process of Jogan Eruption. In: Fuji Volcano. (eds.) Aramaki, S., Fujii, T. Nakada, S. and Miyaji, N. Yamanashi Institute of Environmental Sciences, Yamanashi, Japan. 303-338p.

Tsuchi, R. 2007. Groundwater and springs of Fuji Volcano, Japan. In: Fuji Volcano. (eds.) Aramaki, S., Fujii, T. Nakada, S. and Miyaji, N. Yamanashi Institute of Environmental Sciences, Yamanashi, Japan. 375-387*.

Tsuya, H. 1968. Geology of Volcano Mt. Fuji: Explanatory text of the geologic map of Mt. Fuji (Scale 1:50,000). Geological Survey of Japan, Tsukuba, 24p.

Tsuya, H., Machida, H., Shimozuru, D. 1988. Geologic map of Mt. Fuji. Geological Survey of Japan, 2nd printing, $24 \mathrm{p}$.

Tsuya, H. 1971. Topography and geology of volcano Mt. Fuji. Results of the co-operative scientific survey of Mt. Fuji, Fuji Kyuko Co. Ltd., Tokyo.127p.*

Vernier, A. 1993. Aspects of Ethiopian hydrogeology: From geology and mineral resources of Somalia and its surroundings regions, Ist Agron. Oltremare Firenze Relaz Monogr 113:687-698.

Ymamoto, S. 1970. Hydrologic study of volcano Fuji and its adjacent areas. Geographical Review of Japan 43 (5): 267-284.

Yasuhara, M., Kazahaya, K. Marui, A. 2007. An Isotopic Study on Where, When, and How Groundwater is Recharged in Fuji Volcano, Central Japan. In: Fuji Volcano. (eds.) Aramaki, S., Fujii, T. Nakada, S. and Miyaji, N. Yamanashi Institute of Environmental Sciences, Yamanashi, Japan. 389-405p.

*: In Japanese with English abstract, **: In Japanese. 